\title{
Decolorization of methylene blue by new fungus: Trichaptum biforme and decolorization of three synthetic dyes by Trametes hirsuta and Trametes gibbosa
}

\author{
Hossein Eshghia,*, Zahra Alishahi ${ }^{b}$, Mahmood Zokaei $^{b}$, Aboulfazl Daroodia and Elahe Tabasi $^{\mathrm{b}}$ \\ a Department of Chemistry, School of Sciences, Ferdowsi University of Mashhad, Mashhad, 91775-1436, Iran \\ b Department of Biology, School of Sciences, Ferdowsi University of Mashhad, Mashhad, 91775-1436, Iran \\ ${ }^{*}$ Corresponding author at: Department of Chemistry, School of Sciences, Ferdowsi University of Mashhad, Mashhad, 91775-1436, Iran. Tel.: +98.511.8797660; \\ fax:+98.511.8796416. E-mail address: heshghi@ferdowsi.um.ac.ir (H. Eshghi).
}

\section{ARTICLE INFORMATION}

Received: 26 March 2011

Received in revised form: 16 June 2011

Accepted: 23 June 2011

Online: 31 December 2011

\section{KEYWORDS}

Trametes hirsute

Trametes gibbosa

Trichaptum biforme

Dye decolorization

Methylene Blue

Methyl Green

\begin{abstract}
In order to screen dye decolorization by Trametes hirsuta, Trametes gibbosa and new fungus Trichaptum biforme, Methylene Blue (MB), Methyl Green (MG) and Reactive Black 5 (RB5) were studied in Broth culture at concentrations of 25,50 and $70 \mathrm{ppm}$. Decolorization of these three kind dyes by T. hirsuta decreased by increasing of concentration. Decolorization of RB5 by T. hirsuta was examined in two different medium contains of $\mathrm{Mn}^{2+}$ or veratryl alcohol (VA), as activators. At the presence of laccase activator (VA), RB5 was decolorized 91\% at concentration of $70 \mathrm{ppm}$, and in the medium contains of $\mathrm{MnP}$ activator $\left(\mathrm{Mn}^{2+}\right)$, dye was decolorized less than $50 \%$ at same concentration. Decolorization of RB5 by T. hirsuta was more than decolorization of dye at the presence of $\mathrm{MnP}$ activator $\left(\mathrm{Mn}^{2+}\right)$. T. gibbosa decolorized MB, MG and RB5 more than $80 \%$ in the presence of MnP activator. Decolorization of the three kind dyes by T. gibbosa, was independent of concentration. T. gibbosa decolorized different dyes during 20 days and T. hirsuta did it during 32 days, this is due higher potential of decolorization of synthetic dyes for T. gibbosa than T. hirsuta. Decolorization of MB by new fungus T. biforme was studied in two medium contains of $\mathrm{MnP}$ activator and laccase activator. Rate of decolorization in the presence of MnP activator was more than decolorization in the presence of laccase activator. Decolorization of MB by new fungus T. biforme was higher than decolorization of MB by two other fungi.
\end{abstract}

\section{Introduction}

Environmental pollution containing recalcitrant xenobiotic materials has become one of the major ecological problems. Many of these compounds are major environmental pollutants such as nitrotoluenes, dioxin, organic acid, polychlorinated biphenyls (PCBs), polycyclic aromatic hydrocarbons (PAHs), pesticides, synthetic dyes, wood preservatives, synthetic polymers and olive mill wastewater [1-5]. Most of these compounds are toxic, carcinogenic and highly resistant to degradation [6-8]. Synthetic dyes are extensively used in a number of industries, such as textile dyeing or paper printing. Synthetic dyes represent a large group of chemically different compounds, which are classified by their chromophore as azo, anthraquinone, triphenylmethane, heterocyclic or phthalocyanin dyes $[9,10]$. The total world colorant production is estimated to be about 800000 ton/year. More than 10000 dyes are commercially available and at least $10 \%$ of the used dyestuff enters the environment through wastes [8,11-16]. The elimination of such dye-containing effluents is mostly based on physical and chemical procedures, e.g. adsorption, concentration, chemical transformation and incineration. These methods are rather costly and sometimes produce hazardous products [3,10,17-19]. Therefore, several investigations have been carried out several investigations to identify a cost effective and environmentally acceptable technology that could be applied to remediate the contamination. Bioremediation is one of these techniques that involve almost exclusively microbial processes [20-23]. White rot fungi have been studied as one of the possible agents of biodegradation since their extracellular degradation systems are basically non-specific. This fact that allows the degradation of mixture refractory substances and can be applied to environmental pollutants $[24,25]$.

The primary source of carbon for the white rot fungi is trees and plant cellulose, which is protected by a complex polymer known as lignin. The lignin degrading enzymes such as Manganese peroxidase (MnP) (EC 1.11.1.13), Lignin peroxidase (LiP) (EC 1.11.1.14) and Laccase (Lac) (EC 1.10.3.2) degrade lignin $[26,27]$. Taxonomically, white rot fungi are mostly basidiomycetes, and a few ascomycetes are also capable of white rot decay [28]. Fungal strains have different ligninolytic systems which distinguish them from each other [16,23,29-30]. Laccase requires oxygen and peroxidase need oxygen peroxide for reactions. Phanerochaete chrysosporium was the first fungus that was examined its ability to decolorization [31,32]. A fungus species can degrade pollutants. In contrast of fungi a consortium of bacteria may be needed to completely degrade the same mixture. Also bacteria which rely on various enzymes must first adsorbe the chemicals. Then these chemicals induce the production of enzymes needed for degradation [23]. Hitherto has been studied on ability of different fungi species in dye decolorization [28]. Kling and Neto (1991) [33], studied oxidation of MB by crude lignin peroxidase from Phanerochaete 
chrysosporium. This reaction depended on peroxide concentration. Fungus Coriolos versicolor decolorized Methylene Blue at concentrations 5 and $10 \mathrm{mg} / \mathrm{L}$. At this study various glucose and $\mathrm{NH}_{4} \mathrm{H}_{2} \mathrm{OPO}_{4}$ were effective in rate of decolorization [34].

\section{Experimental}

\subsection{Effect of temperature on growth of fungi}

Trametes hirsuta (Fr.) Pilát., Trametes gibbosa (Pers.) Fr. and Trichaptum biforme (Fr.) Ryvarden were collected in April 2008 from Abbas Abad Forest, in North of Iran. The fungi were growing on dead wood of hornbeam (Carpinus betulus L.) from Betulaceae. Specimens were identified based on morphological features according to Ryvarden and Gilbertson [35]. T. hirsuta based on following features was identified: Basidiocarp annual, effused-reflexed, upper surface hirsute, gray, with brownish margin, cap $8 \mathrm{~cm}$ wide, $5 \mathrm{~cm}$ long and $2 \mathrm{~cm}$ thick. Context trimitic with clamp connection. Hyphal system trimitic. Pores white, 3 per $\mathrm{mm}$. Spores $5 * 2 \mu \mathrm{m}$, smooth, cylindric. Inedible. $T$. gibbosa according to these features was identified: Basidiocarp annual, applanate, semicircular, grayish white, upper surface colored green due to algal growth. Pores creamy-white, elongated and stollike, 2 per mm. Hyphal system trimitic. Spores hyaline, clyndric, $4.5 * 2.5 \mu \mathrm{m}$. T. biforme according to following characters was identified: Basidiocarp annual, imbricate, dimidiate, hirsute to glabrous with age, surface violaceous. Pore surface purple, the pores angular, 5 per $\mathrm{mm}$, tube layer violaceous. Hyphal system dimitic. Cyctidia abundant. Basidiospores cylindric, hyaline, smooth, $6 * 2.5 \mu \mathrm{m}$. To obtain pure culture without contamination, small fragments about $1 \mathrm{~mm}^{3}$ from the inner flesh of the basidiocarps of $T$. hirsuta, T. gibbosa and T. biforme were plated into petri dishes contains of medium culture (Malt Extract Agar (M.E.A.) is the best medium culture for Basidiomycetes) separately and mycelium growing, were repeatedly transferred into new plates until the culture were pure. To ensure that the mycelium growing are T. hirsuta, T. gibbosa and T. biforme, mycelium were observed with a optical microscope. Existance clamp connection, confirmed the desired fungal growth. Stock cultures were stored in M.E.A. plates at $4{ }^{\circ} \mathrm{C}$ and periodically subcultured.

Not all white rot fungi are able to produce all enzymes including laccase, $\mathrm{Mn}$ peroxidase (MnP) and Lignin peroxidase (LiP). Different $5 \mathrm{~mm}$ Agar plugs from the growing margin of $T$. hirsuta, T. gibbosa and T. biforme were inoculated into malt agar plates. Replicates were prepared for fungus and incubated at each of the following temperatures $(15,20,25,30,35,40,50$ and $60{ }^{\circ} \mathrm{C}$ ). The experiment was repeated three times. Growth was followed by measuring radial extension of the mycelium (every $24 \mathrm{~h}$ ) for at least 15 days. Mean growth rates (mm/day) were calculated, to find the optimum growth temperature.

\subsection{Study of optimum $\mathrm{pH}$ for growth of mycelium}

To study the effect of $\mathrm{pH}$ on growing fungi, mycelia were incubated on Malt Extract Broth at different $\mathrm{pH}=4,6,7$ and 9 during 15 days and dry weight of mycelium were measured every 3 days.

\subsection{Dye decolororization experiments}

In order to study of decolorization of three structurally different dyes (Scheme 1) MB (Heterocyclic dye), MG (Triphenylmethane dye) and RB5 (Diazo dye), by T. hirsuta, T. gibbosa and MB by T. biforme were selected. These fungi were grown on broth medium. At first two different medium containing $\mathrm{MnP}$ activator including $\mathrm{Mn}^{2+}$, according to Mohorčič et al. [37] procedure and laccase activator including veratryl alcohol, according to Minussi et al. [36] procedure were used.

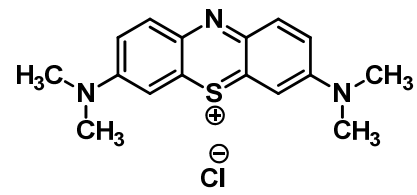

Methylene Blue; Heterocyclic dye $\lambda_{\max }=633 \mathrm{~nm}$

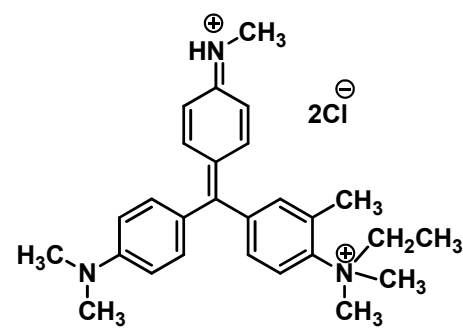

Methyl Green; Triphenylmathane dye $\lambda_{\max }=635 \mathrm{~nm}$

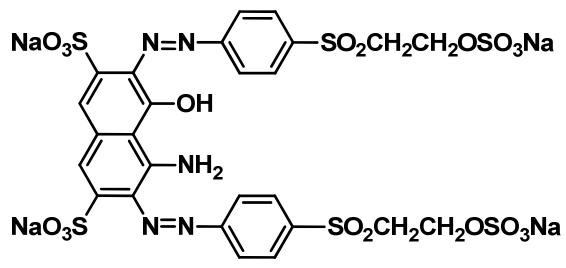

Reactive Black 5; Diazo dye $\lambda_{\max }=603 \mathrm{~nm}$

Scheme 1

The composition of the culture medium to induce laccase production and activation was prepared according to Minussi et al. procedure [36]. The basal medium containing per litre (g/L): malt extract (5.0); peptone (10.0); glucose (20.0); and $\mathrm{CuSO}_{4} .5 \mathrm{H}_{2} \mathrm{O}$ (0.005), (0.5) mM pyrogallol; veratryl alcohol (laccae activator) (0.07); $\mathrm{pH}$ was 4 . The medium for screening Mn Peroxidase production by fungus, prepared according to Mohorčič et al. procedure [37] per litre (g/L) contain of: Glucose (10.0); Yeast Extract (0.2); tartaric acid (3.0); Tween 80 (1.0); $\mathrm{KH}_{2} \mathrm{PO}_{4}(0.2) ; \mathrm{CaCl}_{2}$. $2 \mathrm{H}_{2} \mathrm{O}$ (0.146); $\left(\mathrm{NH}_{4}\right)_{2} \mathrm{HPO}_{4}$ (0.157); $\mathrm{MgSO}_{4}$. $7 \mathrm{H}_{2} \mathrm{O}$ (50.0 mg); $\mathrm{ZnSO}_{4} .7 \mathrm{H}_{2} \mathrm{O}$ (42.5 mg); $\mathrm{MnSO}_{4} . \mathrm{H}_{2} \mathrm{O}$ (MnP activator) $\left(33.8 \mathrm{mg}\right.$ ); $\mathrm{CoCl}_{2} .6 \mathrm{H}_{2} \mathrm{O}(7.0 \mathrm{mg}$ ); $\mathrm{CuCl}_{2}$. $2 \mathrm{H}_{2} \mathrm{O}(0.7 \mathrm{mg}) ; \mathrm{FeCl}_{3}(0.54 \mathrm{mg}) ; \mathrm{NaCl}(0.9 \mathrm{mg})$. pH was 4.5. All chemicals were obtained from Sigma.

The following synthetic dyes were obtained from Sigma: Methylene Blue (MB), Methyl Green (MG). Reactive Black 5 (RB5) was obtained from a national dyeing factory.

To test the ability of fungi to decolorize synthetic dyes in vivo, each dye was membrane-filtered with a $0.25 \mu \mathrm{m}$ cellulose nitrate filter and was concentrated to final concentrations of 25, 50 and $70 \mathrm{ppm}$. The dye disappearance was determined spectrophotometrically (Agilent $8453 \mathrm{UK}$ ). Line equation of tested dyes was obtained by Sigma Plot 8.0. Afterward amount of dye absorptions were placed in equation and were obtained dye concentrations. To obtain percentage of dye removal was used Removal Efficiency formula:

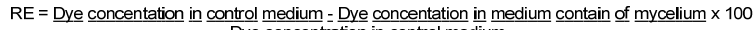
Dye concentration in control medium 
Table 1.Dry weight of mycelium (g) from three fungal species at different $\mathrm{pH}$

\begin{tabular}{|c|c|c|c|c|c|c|c|c|c|c|}
\hline \multirow[t]{2}{*}{$\overline{\text { pH }}$} & \multicolumn{2}{|c|}{ Day 3} & \multicolumn{2}{|c|}{ Day 6} & \multicolumn{2}{|c|}{ Day 9} & \multicolumn{2}{|c|}{ Day 12} & \multicolumn{2}{|c|}{ Day 15} \\
\hline & Mean & $\begin{array}{c}\text { Standard } \\
\text { Deviation }\end{array}$ & Mean & $\begin{array}{c}\text { Standard } \\
\text { Deviation }\end{array}$ & Mean & $\begin{array}{c}\text { Standard } \\
\text { Deviation }\end{array}$ & Mean & $\begin{array}{c}\text { Standard } \\
\text { Deviation }\end{array}$ & Mean & $\begin{array}{l}\text { Standard } \\
\text { Deviation }\end{array}$ \\
\hline \multicolumn{11}{|c|}{ T. hirsuta } \\
\hline 4 & 0.6521 & 0.0023 & 0.9626 & 0.1023 & 1.0678 & 0.0833 & 1.4984 & 0.1787 & 1.6251 & 0.0921 \\
\hline 6 & 0.5110 & 0.0982 & 0.6878 & 0.0832 & 0.9991 & 0.6231 & 1.0023 & 0.0928 & 1.1233 & 0.1972 \\
\hline 7 & 0.2930 & 0.2342 & 0.3940 & 0.0099 & 0.3999 & 0.1798 & 1.0065 & 1.0382 & 1.0382 & 0.3232 \\
\hline 9 & 0.0283 & 0.7002 & 0.0232 & 0.3987 & 0.2331 & 0.4862 & 0.3921 & 0.6523 & 0.5332 & 0.0909 \\
\hline \multicolumn{11}{|c|}{ T. gibbosa } \\
\hline 4 & 0.9210 & 0.0078 & 1.2039 & 0.7577 & 1.5321 & 0.1827 & 1.6342 & 0.1872 & 1.6661 & 0.0123 \\
\hline 6 & 0.5726 & 0.3983 & 0.5999 & 0.2378 & 0.6876 & 0.4726 & 0.7917 & 1.0480 & 0.9899 & 0.8277 \\
\hline 7 & 0.5111 & 0.0887 & 0.5290 & 0.0972 & 0.5654 & 0.0782 & 0.5920 & 0.1873 & 0.6287 & 0.0343 \\
\hline 9 & 0.2167 & 0.2768 & 0.3432 & 0.1762 & 0.3249 & 0.0637 & 0.3498 & 0.1077 & 0.3578 & 0.9733 \\
\hline \multicolumn{11}{|c|}{ T. biforme } \\
\hline 4 & 0.0977 & 0.0763 & 0.4877 & 0.5165 & 0.6890 & 0.0761 & 0.7463 & 0.0370 & 0.7300 & 0.0721 \\
\hline 6 & 0.2890 & 0.5621 & 0.4170 & 0.0125 & 0.6100 & 0.0127 & 0.6909 & 0.0232 & 0.7023 & 1.0990 \\
\hline 7 & 0.2973 & 0.0827 & 0.2999 & 0.1878 & 0.3100 & 0.0232 & 0.6763 & 0.0883 & 0.7011 & 0.9820 \\
\hline 9 & 0.0230 & 0.6162 & 0.0993 & 0.1657 & 0.2983 & 0.0072 & 0.3012 & 0.9792 & 0.4977 & 0.0400 \\
\hline
\end{tabular}

\section{Results and discussion}

\subsection{Effect of temperature on growth of fungi}

Optimum temperature for T. hirsuta, T. gibbosa and T. biforme was 35,30 and $25{ }^{\circ} \mathrm{C}$, respectively. Optimum temperature for pured laccase and $\mathrm{MnP}$ activity was 40 to $60^{\circ} \mathrm{C}$ [28], but at this experiment decolorization was determined in vivo and at these temperatures growing of both T. hirsuta, $T$. gibbosa and T. biforme stoped. Therefore the experiments were followed at 35,30 and $25^{\circ} \mathrm{C}$, respectively.

\subsection{Study of optimum $\mathrm{pH}$ for growth of mycelium}

Three fungal mycelium at different studied $\mathrm{pH}=4,6,7$, and 9 were compared at Table 1 . Dry weight of mycelium (g) from three fungal species at different $\mathrm{pH}$ and times were measured. Therefore optimum $\mathrm{pH}$ for highest growth of T. hirsuta, $T$. gibbosa and T. biforme was 4 (Table 1).

\subsection{Dye decolorization experiments}

\subsubsection{Decolorization by Trametes hirsuta}

Three dyes (MB, MG and RB5) were examined at three concentrations of 25,50 and $70 \mathrm{ppm}$ in medium culture containing the $\mathrm{Mn}^{2+}$ (Mn peroxidase activator). $\mathrm{MB}$ at concentrations of 25, 50 and $70 \mathrm{ppm}$ was degraded more than $80 \%$ at $16^{\text {th }}$ day. It is agree to Novotný et al. [3] that reported Irpex lacteus (Fr.) Fr. Decolorized MB by $80 \%$ within two weeks. This experiment was continued until 32 day. Rate of decolorization was reduced by increasing concentration, so that at concentration of $25 \mathrm{ppm}, \mathrm{MB}$ was degraded completely $(100 \%)$ and at 50 and $70 \mathrm{ppm}, \mathrm{MB}$ degraded $90 \%$ and $80 \%$ respectively (Figure 1).

Rate of decolorization of MG at concentration 25 ppm was less than decolorization at concentrations 50 and $70 \mathrm{ppm}$ until $22^{\text {th }}$ day, but in following days, rate of decolorization was achieved more than 50 and $70 \mathrm{ppm}$. Dye was decolorized completely at $24^{\text {th }}$ day. MG was decolorized at concentrations 50 and $70 \mathrm{ppm}$ at $32^{\text {th }}$ day (Figure 2). Results showed decolorizatiion of MB was more than MG by T. hirsuta, it is agree with this report that highly substituted triphenylmethane dye such as MG required longer time to be decolorized or could only be decolorized to a certain extent [38].

RB5 was decolorized $91 \%$ at concentration of $70 \mathrm{ppm}$ in medium contains of laccase activator (VA), but in the medium contains of $\mathrm{MnP}$ activator $\left(\mathrm{Mn}^{2+}\right)$, dye was decolorized less than $50 \%$. This dye was decolorized completely at concentrations 25 ppm and $50 \mathrm{ppm}$ in the presece of VA while in the presece of $\mathrm{Mn}^{2+}$ rate of decolorization was achieved 65\% (Figure 3 and 4). RB5 was decolorized slower than MB and MG, because of its complex structure. It is notable that some compounds that were rapidly decolorized by $\mathrm{MnP}$ were resistant to other enzymes and the other compounds which are resistant to $\mathrm{MnP}$ [39]. Moreover, $\lambda_{\max }$ of RB5 was changed during study. $\lambda_{\max }$ of RB5 changed from 602 at day one to 610 at day 8 and to 616 and 620 at days 16 and 32, respectively. Therefore RB5 may be converted to other dyes products and this delay the decolorization. Spectrum of MB and MG showed complete decolorization.

Rodríguez Couto et al., [40] studied of the effect of redox mediators (2,20-azino-bis(3-ethylbenzothiazoline-6-sulfonic acid) (ABTS) and 1-hydroxybenzotriazole (HBT) Remazol Brilliant Blue R (RBBR) on synthetic dyes: Sella Solid Red and Luganil Green by laccase from Trametes hirsuta. Result showed higher activities of enzyme in the presence of mediators than those obtained without mediators addition. HBT showing a decolourization percentage of $88 \%$ in $10 \mathrm{~min}$ for Sella Solid Red and of $49 \%$ in $20 \mathrm{~min}$ for Luganil Green.

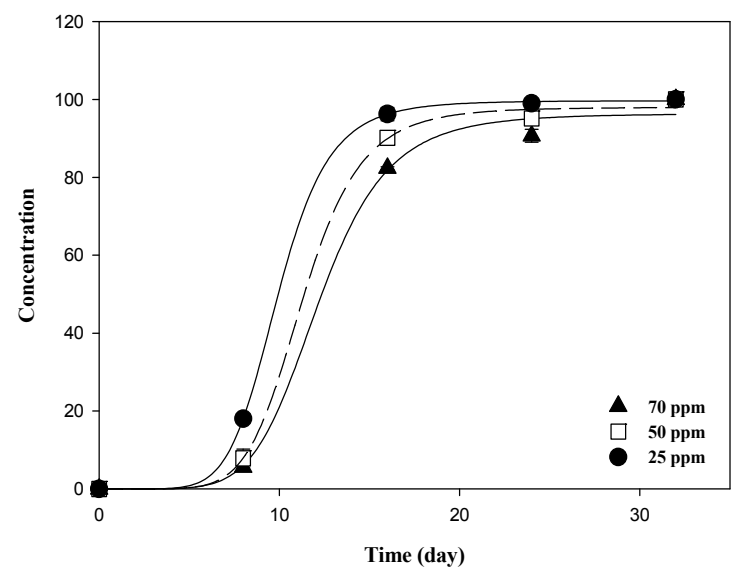

Figure 1. Removal Efficiency (\%) of MB at three different concentrations within 32 days by $T$. hirsute.

\subsubsection{Decolorization by T. gibbosa}

Decolorization of MB, MG and RB5 by T. gibbosa was studied during 20 days at three concentrations $(25,50$ and 70 ppm) in medium contains of $\mathrm{Mn}^{2+}$. $\mathrm{MB}$ was degraded completely at concentration of $25 \mathrm{ppm}$ at $20^{\text {th }}$ day. Decolorization of $\mathrm{MG}, \mathrm{MB}$ and RB5 was independent of concentration. Decolorization rate of MB at $70 \mathrm{ppm}$, was less than $50 \mathrm{ppm}$ in the first 8 days, but in following days the rate of decolorization at $70 \mathrm{ppm}$ was more than $50 \mathrm{ppm}$ (Figure 5). 


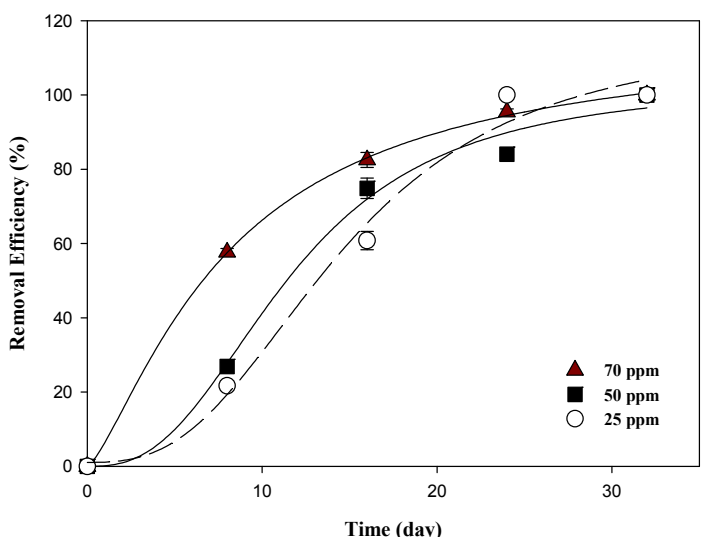

Figure 2. Removal Efficiency (\%) of MG at 25, 50 and 70 ppm by T. hirsuta in medium contain of $\mathrm{MnP}$ activator within 40 days.

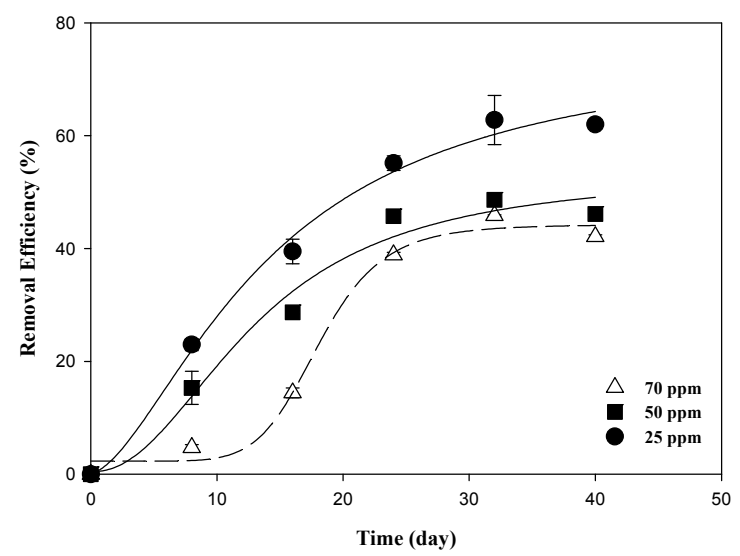

Figure 3. Removal Efficiency (\%) of RB5 in medium contain of MnP activator within 40 days by $T$. hirsute.

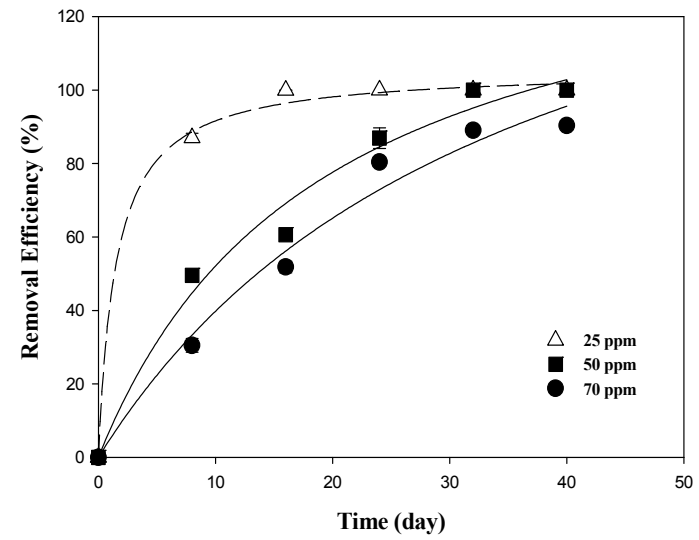

Figure 4. Removal Efficiency (\%) of RB5 in culture contain of Laccase activator within 40 days by T. hirsute.

MG was decolorized completely (100\%) at concentration of 25 at $8^{\text {th }}$ day. At concentrations 50 and $70 \mathrm{ppm}$, MG was decolorized $97 \%$ and $80 \%$ at $20^{\text {th }}$ day (Figure 6).

RB5 was decolorized completely $(100 \%)$ at $16^{\text {th }}$ day. Dye was decolorized more than $80 \%$ at $20^{\text {th }}$ day at 50 and $70 \mathrm{ppm}$, (Figure 7). Figures showed decolorization of MG was more than MB by T. gibbosa, that it is not agreed with Osma et al. that expressed highly substituted Triphenylmathane need more time to decolorization [38]. It is likely that in addition to dye structure is effective in the decolorization, the type of fungus is effective in the decolorization too [38]. The decolorization of Reactive Black 5 (RB5) by immobilised Funalia trogii was investigated by Mazmanci and Unyayar [41]. The effect of mycelial age was studied, and decolorization rate of a 3-day-old age culture was higher than those of 0 - and 6-day-old cultures. The growth of $F$. trogii was inhibited by all tested dye concentrations with compared to controls.

Reactive Black 5 was used in screening 25 fungal strains. It was shown that the concentrations of the constituents had to be reduced to allow fungal growth. Purified manganese peroxidase prepared from Bjerkandera adusta was tested for decolorization of several artificial dye baths. Based on absorbance units, the largest reduction was achieved with the Reactive Black 5 and Acid Orange 7 dye baths [37]

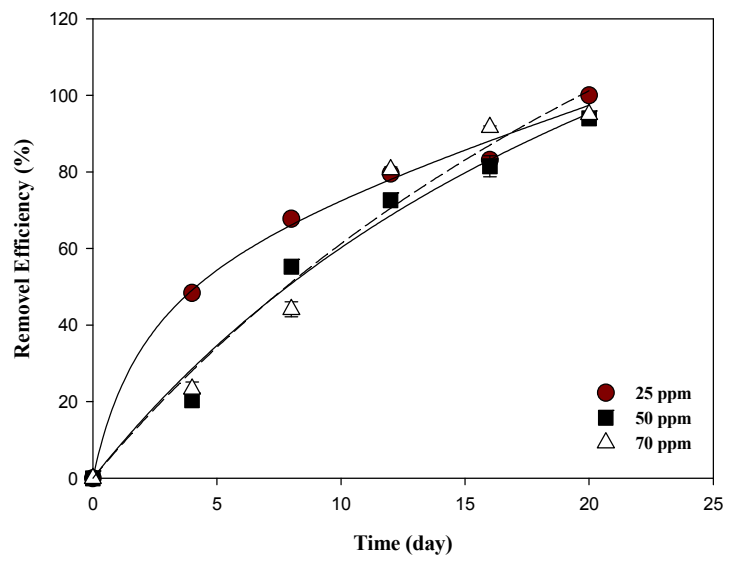

Figure 5. Removal Efficiency (\%) of MB by T. gibbosa within 20 days.

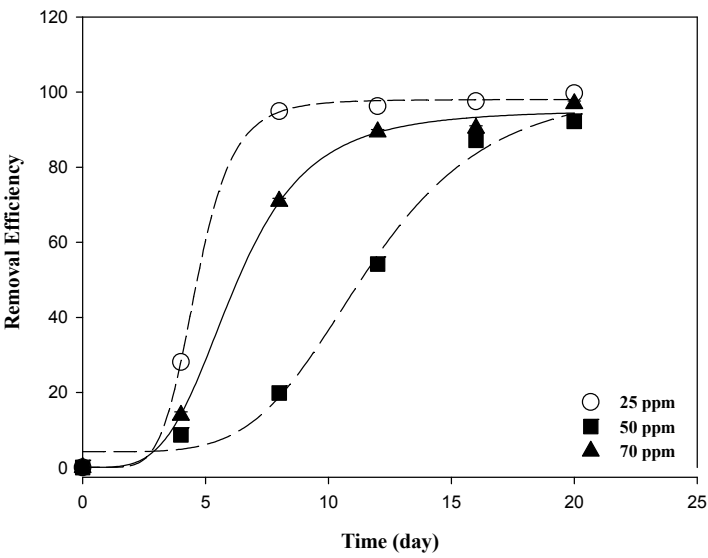

Figure 6. Removal Efficiency (\%) of MG by T. gibbosa during 20 days.

\subsubsection{Decolorization by Trichaptum biforme}

Decolorization of MB was studied in two medium contains of $\mathrm{MnP}$ activator and laccase activator by new fungus T. biforme during 20 days. Maximum decolorization of MB in medium culture contains of $\mathrm{Mn}^{2+}$ was achieved $40 \%$ and in medium contains of VA was achieved $98 \%$ at $20^{\text {th }}$ day (Figure 8 and 9 ). According to cures, can be claimed $\mathrm{MnP}$ is the main enzyme of T. boforme in dye decolorization. The most important result obtained is that in medium contain of $\mathrm{MnP}$ activator, new fungus $T$. biforme, decolorized $\mathrm{MB}$ higher than two other species. 
Table 2. Dry weight of mycelium (g) from three fungal species at different concentrations (ppm) of three kind dye.

\begin{tabular}{|c|c|c|c|c|c|c|c|c|c|c|}
\hline & \multicolumn{2}{|c|}{ Day 0} & \multicolumn{2}{|c|}{ Day 8} & \multicolumn{2}{|c|}{ Day 16} & \multicolumn{2}{|c|}{ Day 24} & \multicolumn{2}{|c|}{ Day 32} \\
\hline & Mean & $\begin{array}{l}\text { Standard } \\
\text { Deviation }\end{array}$ & Mean & $\begin{array}{l}\text { Standard } \\
\text { Deviation }\end{array}$ & Mean & $\begin{array}{l}\text { Standard } \\
\text { Deviation }\end{array}$ & Mean & $\begin{array}{l}\text { Standard } \\
\text { Deviation }\end{array}$ & Mean & $\begin{array}{l}\text { Standard } \\
\text { Deviation }\end{array}$ \\
\hline \multicolumn{11}{|c|}{ T. hirsuta at present of MB } \\
\hline $25 \mathrm{ppm}$ & 0 & 0 & 0.0759 & 1.0001 & 0.3472 & 0.4630 & 0.3515 & 0.6032 & 0.4001 & 0.0984 \\
\hline $50 \mathrm{ppm}$ & 0 & 0 & 0.1020 & 0.1009 & 0.3116 & 0.2630 & 0.2480 & 0.1231 & 0.3045 & 0.1211 \\
\hline $70 \mathrm{ppm}$ & 0 & 0 & 0.0826 & 0.0039 & 0.3116 & 0.0023 & 0.2839 & 0.1290 & 0.3133 & 0.0824 \\
\hline Control & 0 & 0 & 0.1972 & 0.0763 & 0.3016 & 0.0342 & 0.4888 & 0.0553 & 0.6380 & 0.6101 \\
\hline \multicolumn{11}{|c|}{ T. hirsuta at present of MG } \\
\hline $25 \mathrm{ppm}$ & 0 & 0 & 0.1275 & 0.0923 & 0.2686 & 0.4350 & 0.2135 & 0.3092 & 0.2240 & 0.0621 \\
\hline $50 \mathrm{ppm}$ & 0 & 0 & 0.1456 & 0.4362 & 0.2855 & 0.0211 & 0.2382 & 0.1097 & 0.2400 & 0.0626 \\
\hline 70 ppm & 0 & 0 & 0.1578 & 0.0753 & 0.3202 & 0.3430 & 0.2696 & 0.5372 & 0.2690 & 0.0200 \\
\hline Control & 0 & 0 & 0.2258 & 0.3525 & 0.3362 & 0.2542 & 0.4687 & 0.9999 & 0.6599 & 0.0201 \\
\hline
\end{tabular}

\begin{tabular}{|c|c|c|c|c|c|c|c|c|c|c|c|c|}
\hline & \multicolumn{2}{|c|}{ Day 0} & \multicolumn{2}{|c|}{ Day 8} & \multicolumn{2}{|c|}{ Day 16} & \multicolumn{2}{|c|}{ Day 24} & \multicolumn{2}{|c|}{ Day 32} & \multicolumn{2}{|c|}{ Day 40} \\
\hline & Mean & $\begin{array}{l}\text { Standard } \\
\text { Deviation }\end{array}$ & Mean & $\begin{array}{l}\text { Standard } \\
\text { Deviation }\end{array}$ & Mean & $\begin{array}{l}\text { Standard } \\
\text { Deviation }\end{array}$ & Mean & $\begin{array}{l}\text { Standard } \\
\text { Deviation }\end{array}$ & Mean & $\begin{array}{c}\text { Standard } \\
\text { Deviation }\end{array}$ & Mean & $\begin{array}{c}\text { Standard } \\
\text { Deviation }\end{array}$ \\
\hline \multicolumn{13}{|c|}{ T. hirsuta at present of RB5 and MnP activator } \\
\hline $25 \mathrm{ppm}$ & 0 & 0 & 0.076 & 0.0380 & 0.0850 & 1.0972 & 0.1150 & 0.0821 & 0.1320 & 0.1452 & 0.1500 & 0.2234 \\
\hline $50 \mathrm{ppm}$ & 0 & 0 & 0.0450 & 0.0983 & 0.0735 & 0.0762 & 0.0915 & 0.5442 & 0.1112 & 0.3410 & 0.1187 & 0.1650 \\
\hline $70 \mathrm{ppm}$ & 0 & 0 & 0.0355 & 0.0732 & 0.0700 & 0.0722 & 0.0895 & 0.1600 & 0.1010 & 0.4726 & 0.1000 & 0.2076 \\
\hline Control & 0 & 0 & 0.0271 & 0.0029 & 0.0410 & 0.0650 & 0.0574 & 0.0032 & 0.1021 & 0.2280 & 0.1106 & 0.1092 \\
\hline \multicolumn{13}{|c|}{ T. hirsuta at present of RB5 and laccase activator } \\
\hline $25 \mathrm{ppm}$ & 0 & 0 & 0.0649 & 0.0901 & 0.1886 & 0.0452 & 0.1924 & 0.2870 & 0.2163 & 0.0541 & 0.2320 & 0.5200 \\
\hline $50 \mathrm{ppm}$ & 0 & 0 & 0.1248 & 0.1652 & 0.2498 & 0.0521 & 0.2607 & 0.0175 & 0.2845 & 0.4007 & 0.2913 & 0.3120 \\
\hline $70 \mathrm{ppm}$ & 0 & 0 & 0.1408 & 0.2571 & 0.2361 & 0.0099 & 0.2985 & 0.2208 & 0.3362 & 0.1940 & 0.3872 & 0.1209 \\
\hline Control & 0 & 0 & 0.2258 & 0.0123 & 0.3016 & 0.2310 & 0.4687 & 0.7610 & 0.6599 & 0.6520 & 0.7010 & 0.0212 \\
\hline
\end{tabular}

\begin{tabular}{|c|c|c|c|c|c|c|c|c|c|c|c|c|}
\hline & \multicolumn{2}{|c|}{ Day 0} & \multicolumn{2}{|c|}{ Day 4} & \multicolumn{2}{|c|}{ Day 8} & \multicolumn{2}{|c|}{ Day 12} & \multicolumn{2}{|c|}{ Day 16} & \multicolumn{2}{|c|}{ Day 20} \\
\hline & Mean & $\begin{array}{l}\text { Standard } \\
\text { Deviation }\end{array}$ & Mean & $\begin{array}{c}\text { Standard } \\
\text { Deviation }\end{array}$ & Mean & $\begin{array}{c}\text { Standard } \\
\text { Deviation }\end{array}$ & Mean & $\begin{array}{c}\text { Standard } \\
\text { Deviation }\end{array}$ & Mean & $\begin{array}{l}\text { Standard } \\
\text { Deviation }\end{array}$ & Mean & $\begin{array}{l}\text { Standard } \\
\text { Deviation }\end{array}$ \\
\hline \multicolumn{13}{|c|}{ T. gibbosa at present of MB } \\
\hline $25 \mathrm{ppm}$ & 0 & 0 & 0.0730 & 0.0342 & 0.1721 & 0.0736 & 0.3328 & 0.9660 & 0.3210 & 0.0572 & 0.3019 & 0.2222 \\
\hline $50 \mathrm{ppm}$ & 0 & 0 & 0.0841 & 0.0432 & 0.1345 & 0.2611 & 0.3401 & 1.2323 & 0.3105 & 0.2078 & 0.2854 & 0.0632 \\
\hline $70 \mathrm{ppm}$ & 0 & 0 & 0.1011 & 0.6540 & 0.1899 & 0.1203 & 0.3542 & 0.3230 & 0.3540 & 0.2532 & 0.2894 & 0.3034 \\
\hline Control & 0 & 0 & 0.1121 & 0.5420 & 0.2500 & 0.3232 & 0.2891 & 0.1235 & 0.3120 & 0.0162 & 0.3355 & 0.0834 \\
\hline \multicolumn{13}{|c|}{ T. gibbosa at present of MG } \\
\hline $25 \mathrm{ppm}$ & 0 & 0 & 0.1367 & 0.3650 & 0.1621 & 0.0343 & 02698 & 0.0213 & 0.3500 & 0.0322 & 0.3121 & 0.0632 \\
\hline $50 \mathrm{ppm}$ & 0 & 0 & 0.1811 & 0.6300 & 0.2710 & 0.1763 & 0.3287 & 0.0232 & 0.3801 & 0.8830 & 0.3289 & 0.5432 \\
\hline 70 ppm & 0 & 0 & 0.1865 & 0.0937 & 0.2141 & 0.2310 & 0.2756 & 0.3420 & 0.3435 & 0.3200 & 0.2178 & 0.0521 \\
\hline Control & 0 & 0 & 0.1298 & 0.2432 & 0.2509 & 0.2123 & 0.2911 & 0.0323 & 0.3111 & 0.3280 & 0.3120 & 0.0231 \\
\hline \multicolumn{13}{|c|}{ T. gibbosa at present of RB5 } \\
\hline $25 \mathrm{ppm}$ & 0 & 0 & 0.0689 & 0.2222 & 0.1432 & 0.0239 & 0.1784 & 0.5332 & 0.2461 & 1.0320 & & \\
\hline $50 \mathrm{ppm}$ & 0 & 0 & 0.0721 & 0.2093 & 0.1626 & 0.9343 & 0.1411 & 0.0434 & 0.2698 & 0.2373 & & \\
\hline 70 ppm & 0 & 0 & 0.0688 & 0.0099 & 0.0854 & 0.3043 & 0.1532 & 0.3432 & 0.1987 & 0.2123 & & \\
\hline Control & 0 & 0 & 0.1189 & 0.1023 & 0.2487 & 0.0342 & 0.2811 & 0.0994 & 0.3210 & 0.1235 & & \\
\hline \multicolumn{13}{|c|}{ T. biforme at present of MB } \\
\hline 25 ppm & 0 & 0 & 0.0800 & 0.0099 & 0.1045 & 0.4623 & 0.1220 & 0.2673 & 0.1324 & 0.7222 & 0.1220 & 0.2362 \\
\hline $50 \mathrm{ppm}$ & 0 & 0 & 0.0361 & 0.2782 & 0.0511 & 0.1977 & 0.0575 & 0.7522 & 0.0656 & 0.0723 & 0.1022 & 0.2366 \\
\hline
\end{tabular}

\subsection{Effect of dye on dry weight of mycelium}

To obtain the amount of fungal growth in the presence of dye, dry weight of mycelium which was grown at different concentrations of dyes, was determined (Table 2). Dry weight of mycelium of $T$. hirsuta in medium culture contains of MB was more than MG and RB5. These results showed less toxicity of $\mathrm{MB}$ in comparison with other dyes. Also different concentrations of MB did not show any significant effect on fungal growth. In medium containing the MG, mycelium growth decreased with increasing concentration. In medium containing RB5 and laccase activator, dry weight increased surprisingly with increasing dye concentration. In MnP medium in the presence of RB5, maximum growth was achived in $25 \mathrm{ppm}$. Dye at 50 and $70 \mathrm{ppm}$ was toxic and reduced the mycelium growth, therefore, in medium contains of $\mathrm{MnP}$ activator and RB5, either growth of mycelium and decolorization decreased by increasing dye concentration. In laccase activator medium, fungal mycelium could obtain essential materials from culture for growing, therefore produce enzyme and degrade dye. Also was compared dry weight of $T$. hirsuta in medium containing of three dyes at $25 \mathrm{ppm}$. These results confirm finding about less toxicity of $\mathrm{MB}$, and preference of laccase activator medium in the decolorization of RB5.

Growth of T. gibbosa at different concentrations of MB, MG and RB5 in comparison with control medium was achived. Results showed MB and MG are less toxic for T. gobbosa. In medium containing the RB5, mycelium growth significantly decreased. These results correlate with data of (Figure 5-7).

Dry weight of $T$. biforme at concentration of $25 \mathrm{ppm}$ was obtained more than $50 \mathrm{ppm}$ (Table 2).

\section{Conclusion}

We studied dye decolorization of three different synthetic dyes (Remazol Black 5, Diazo dye; Methylene Blue, Heterocyclic dye; Methyl Green, Triphenylmethane dye) by Trametes hirsuta, Trametes gibbosa and Trichaptum biforme from white rot fungi. At this study was determined kind of fungus is effective on decolorization as T. gibbosa decolorized MG (has highly substituted and need more time to decolorization) faster than MB while T. hirsuta could not do it. Decolorization of MB by new fungus T. biforme in medium contains of $\mathrm{Mn}^{2+}$ was more than decolorization of this dye in medium contains of VA that showed $\mathrm{MnP}$ is main enzyme of $T$. biforme in dye decolorization. The most important result is new fungus $T$. biforme decolorized MB higher than two other species and can more testing be done on it and could be used in future.

\section{Acknowledgements}

The authors are grateful to Dr. Jamil Vaezi and Samira Hozhabr for their helpful comments and collaborations. 


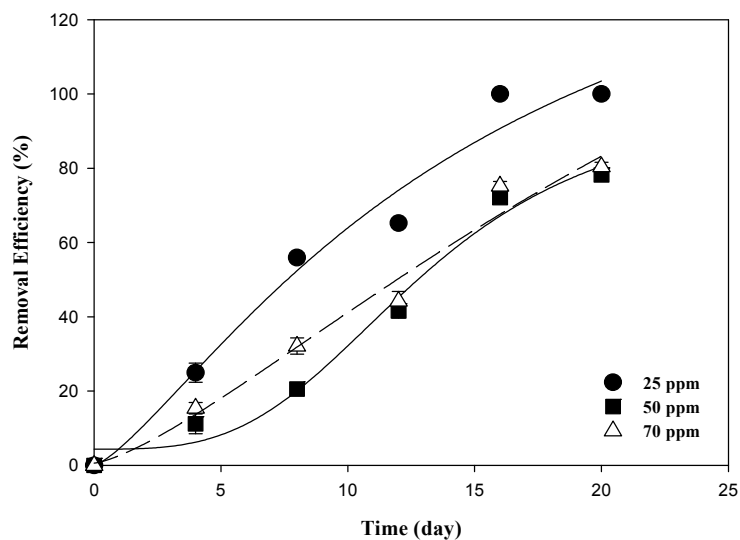

Figure 7. Removal Efficiency (\%) of RB5 by T. gibbosa within 20 days.

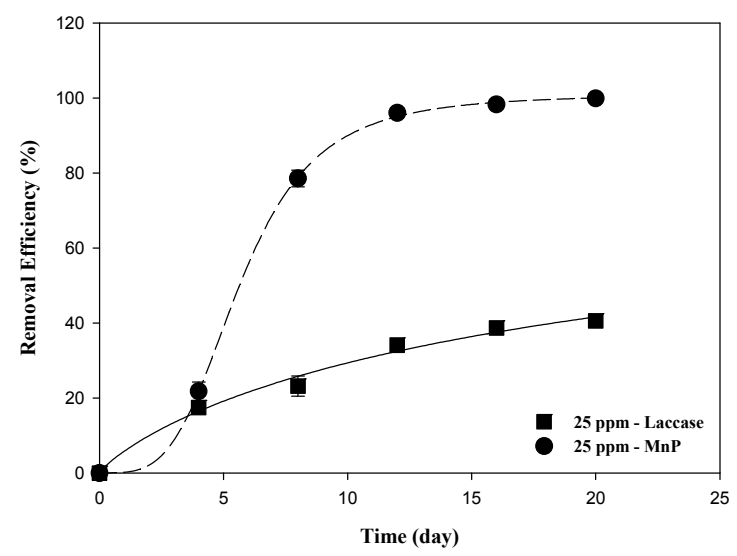

Figure 8. Comparison of removal efficiency of MB by T. biforme at concentration of $25 \mathrm{ppm}$ in medium contain of laccase activator and $\mathrm{MnP}$ activator.

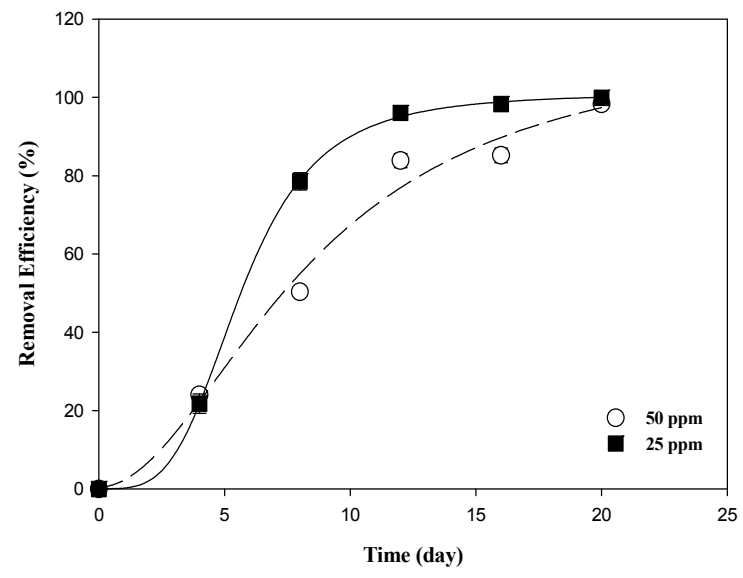

Figure 9. Removal efficiency of MB by T. biforme at concentrations of $25 \mathrm{ppm}$ and $50 \mathrm{ppm}$, in medium contain of $\mathrm{MnP}$ activator.

\section{References}

[1]. Bayman, P.; Radkar, G. Int. Biodeterior. Biodegrad. 1997, 39, 45-53.

[2]. Hammel, K. E.; Moen, M. A. Enzyme Microb. Technol. 1991, 13, 15-18.

[3]. Novotny, C.; Svobodova, K.; Kasinath, A.; Erbanova, P. Int. Biodeterior. Biodegrad. 2004, 54, 215-223.

[4]. Ollikka, P.; Alhonmaki, K.; Leppanen, V. M.; Glumoff, T.; Raijola, T.; Suominen, I. Appl. Environ. Microbiol. 1993, 59, 4010- 4016.
[5]. Pointing, S. Appl. Microbiol. Biotechnol. 2001, 57, 20-33.

[6]. Eichlerova, I.; Homolka, L.; Nerud, F. Dyes Pigm. 2007, 75, 38-44.

[7]. Hamedaani, H. R.; Sakurai, A.; Sakakibara, M. Dyes Pigm. 2007, 72 157-162.

[8]. Trovaslet, M.; Enaud, E.; Guiavarch, Y.; Corbisir, A. M.; Vanhulle, S. Enzyme Microb. Technol. 2007, 41, 368-376.

[9]. Eichlerova, I.; Homolka, L.; Benada, O.; Kofronova, O.; Hubalek, T. Nerud, N. Chemosphere. 2007, 69, 795-802.

[10]. Robinson, T.; McMullan, G.; Marchant, R.; Nigam, P. Bioresour. Technol 2001, 77, 247-255.

[11]. Abadulla, E.; Tzanov, T.; Costa, S.; Robra, K .H.; Cavaco-Paulo, A.; Gubitz, G. M. Appl. Environ. Microbiol. 2000, 66, 3357- 3362.

[12]. Asgher, M.; Azim, N.; Bhatti, H. N. Biochem. Eng. J. 2009, 47, 61-65.

[13]. Levin, L.; Forchiassin, F.; Ramos, A. M. Mycologia. 2002, 94, 377-383.

[14]. Madhavi, S.; Revankar, S.; Lele, S. Bioresour. Technol. 2007, 98, 775780.

[15]. Palmieri, G.; Giardina, P.; Bianco, C.; Fontanella, B.; Sannita, G. Appl. Environ. Microbiol. 2000, 66, 920-924.

[16]. Palmieri, G.; Cennamo, G.; Sannia, G. Enzyme Microb. Technol. 2005 36, 17-24.

[17]. Dominguez, A.; Rodriguez Couto, S.; Sanroman, A. World J. Microbiol. Biotechnol. 2005, 21, 405-409.

[18]. Lin, S.; Peng, F. Water Resour. 1994, 28, 277-282.

[19]. Murugesan, K.; Nam, I. H.; Kim, Y. M.; Chang, Y. S. Enzyme Microb. Technol. 2006, 40, 1662-1672.

[20]. Balba, M. T.; Al-Daher, R.; Al-Awadhi, N. Environ. Int. 1998, 24, 163173.

[21]. Kauffmann, C.; Petersen, B. R.; Bjerrum, M. J. J. Biorheol. 1999, 73, 7174.

[22]. Walter, M.; Boul, L.; Chong, R.; Ford, C. J. Environ. Manage. 2004, 71, 361-369.

[23]. Yateem, A.; Balba, M. T.; Al-Awadhi, N. Environ. Int. 1998, 24, 181-187.

[24]. Boer, C. G.; Obici, L.; de Souza, C. G.; Peralta, R. M. Bioresour. Technol. 2004, $94,107-112$

[25]. Quaratino, D.; Federici, F.; Petruccioli, M.; Fenice, M.; D'Annibale, A Anton Leeuw Int. J. G. 2007, 91, 57-69.

[26]. Mayer, A. M.; Staples, R. C. Phytochemistry 2002, 60, 551-565.

[27]. Meysami, P.; Baheri, H. Adv. Environ. Res. 2003, 7, 881-887.

[28]. Asgher, M.; Bhatti, H. N.; Ashraf, M.; Legge, R. Biodegradation. 2008 19, 771-783.

[29]. Keum, Y. S.; Li, Q. X. Chemospher. 2004, 56, 23-30.

[30]. Glenn, J. K.; Gold, M. H. Arch. Biochem. Biophys. 1985, 242, 329-341.

[31]. Singh, H. Mycoremediation: fungal bioremediation (Hoboken/New Jersey: John Wiley \& Sons, Inc) 2006

[32]. Zouari-Mechichi, H.; Mechichi, T.; Dhouib, A.; Sayadi, S.; Martinez, A T.; Martinez, M. J. Enzyme Microb. Technol. 2006, 39, 141-148.

[33]. Kling, S. H.; Neto, J. S. A. J. Biotechnol. 1991, 21, 295-300.

[34]. Mazmanci, M. A.; Unyayar, A.; Ekiz, H. I. 2002, 11, 254-258.

[35]. Ryvarden. L.; Gilbertson. R. L. European Polypores, Lubrecht \& Cramer Ltd., Oslo, 1993.

[36]. Minussi, R. C.; Pastore, G. M.; Duran, N. Bioresour. Technol. 2007, 98 , 158-164.

[37]. Mohorcic, M.; Teodorovic, S.; Golob, V.; Friedrich, J. Chemospher. 2006 63, 1709-1711.

[38]. Osma, J. F.; Toca Herrera, J. L.; Rodriguez Couto, S. Dyes Pigm. 2007, $75,32-37$

[39]. Gadd, G. M. Fungi in bioremediation (Cambridge University Press, New York) 2001.

[40]. Rodriguez Couto, S.; Sanroman, M.; Gubitz, G. M. Chemosphere 2005, 58, 417-422

[41]. Mazmanci, M. A.; Unyayar, A. Process Biochem. 2005, 40, 337-342. 